\title{
WATER UPTAKE, PRIMING, DRYING AND STORAGE EFFECTS IN Cassia excelsa Schrad SEEDS
}

\author{
JELLER, H., ${ }^{1}$ PEREZ, S. C. J. G. A. ${ }^{1}$ and RAIZER, J. ${ }^{2}$ \\ ${ }^{1}$ Departamento de Botânica, Universidade Federal de São Carlos, C.P. 676, CEP 13565-905, \\ São Carlos, SP, Brazil \\ ${ }^{2}$ Departamento de Zoologia/PG-Ecologia, UNICAMP, C.P. 6109, Campinas, SP, Brazil \\ Correspondence to: Helma Jeller, Departamento de Botânica, Universidade Federal de São Carlos, C.P. 676, \\ CEP 13565-905, São Carlos, SP, Brazil, e-mail: dscp@ power.ufscar.br \\ Received December 12, 2001 - Accepted May 9, 2002 - Distributed February 28, 2003
}

(With 3 figures)

\begin{abstract}
The aims of this study were to evaluate the effects of osmotic potential on the water uptake curve in Cassia excelsa seeds and use the results to analyze the effects of dehydration and storage on primed seed germination. Seeds were imbibed in distillad water and polyethylene glicol (PEG 6000) osmotic solutions at $-0.2,-0.4$, and $-0.6 \mathrm{MPa}$, at $20^{\circ} \mathrm{C}$. The radicle emergence and seed moisture content were evaluated at 6-hour intervals during 240 hours. Afterwards, seeds were primed in distillad water and PEG 6000 solutions at $-0.2,-0.4$, and $-0.6 \mathrm{MPa}$ for $48,72,96$, and 168 hours at $20^{\circ} \mathrm{C}$, followed by air drying and storage for 15 days at $5^{\circ} \mathrm{C}$. The lower the osmotic potential, the higher the time required for priming. The osmoconditioning yields benefits with PEG solutions at 0.0 and $-0.2 \mathrm{MPa}$; seed improvements were maintained during storage for 15 days at $5^{\circ} \mathrm{C}$, but were reverted by seed drying.
\end{abstract}

Key words: seed, germination, osmoconditioning imbibition, drying.

\section{RESUMO}

Efeito da embebição e do condicionamento osmótico, seguidos de secagem e armazenamento, em sementes de Cassia excelsa Schrad

O presente trabalho teve por objetivo avaliar os efeitos do potencial osmótico sobre a curva de absorção de água de sementes de $C$. excelsa e, a partir deste, o melhor tempo de embebição, para então verificar o efeito do condicionamento osmótico seguido de secagem e armazenamento na germinação. No primeiro, as sementes foram submetidas à embebição em água destilada e em soluções osmóticas de PEG 6000 a $-0,2,-0,4$ e $-0,6 \mathrm{MPa}$, a $20^{\circ} \mathrm{C}$, avaliando-se a emergência da radícula e o grau de umidade das sementes a cada 6 horas, até um total de 240 horas. Para o condicionamento osmótico, as sementes foram colocadas para embeber em água destilada e em soluções de PEG a -0,2, -0,4 e-0,6 MPa por 48, 72, 96 e 168 horas a $20^{\circ} \mathrm{C}$. Posteriormente, foram submetidas ou não à secagem até atingirem o peso inicial anterior à embebição, seguidos ou não por armazenamento a $5^{\circ} \mathrm{C}$ por 15 dias. A redução do potencial osmótico aumenta o tempo necessário para o condicionamento osmótico. As sementes de $C$. excelsa respondem positivamente ao condicionamento em água destilada ou soluções de PEG - $0,2 \mathrm{MPa}$, sendo mantidas essas respostas durante o armazenamento por 15 dias a $5^{\circ} \mathrm{C}$, contudo, a secagem das sementes reverte esses efeitos positivos.

Palavras-chave: germinação, embebição, condicionamento osmótico, secagem. 


\section{INTRODUCTION}

Cassia excelsa Schrad (or Senna spectabilis) is a woody legume common in Northeastern Brazilian shrubland. Due to its small size, it is recommended for use in urban arborization and recuperation of degraded areas. Seed production is irregular with low germination percentage in natural conditions due to the integument impermeability.

According to Vertucci (1989), many factors can influence the imbibition and germination process, among them integument composition and permeability water availability in the environment, hydrostatic pressure, temperature, and seed physiological condition.

The study of the imbibition curve is very important, specially for the development of pregermination techniques aimed at improving seed physiological quality (Lopes et al., 2000) by detecting the reversion point of the imbibition process without damaging the embryo. This is the basic principle of the osmoconditioning technique which consists of allowing pre-germination metabolic activities to occur but without the radicle emerging (Bradford, 1986). The osmoconditioning or "priming" can be used for increasing the germination rate, uniformity of emergence, and the capacity of seeds to withstand adverse environmental effects (Nath et al., 1991; Khan, 1992; Braccini et al., 1997).

The optimum condition required for osmoconditioning varies among the species as well as in relation to the osmotic condition. Under favorable conditions, the mobilization of reserves; activation and renewed synthesis of some enzymes; DNA and RNA synthesis; production of ATP; and repairs of damage in the membrane system are initiated during osmotic conditioning (Bray, 1995). When the obstacle to germination is removed, rapid embryo growth is observed. Several physiological and biochemical changes occur in seeds during the treatment or as a consequence of osmoconditioning. These changes include macromolecular synthesis, activity of several enzymes, increased germination vigour, and release from seed dormancy (Fu et al., 1988; Smith \& Coob, 1992; Sung \& Chang, 1993; McDonald, 1998).

After osmotic conditioning, the seeds can be dried back to the initial moisture content and stored until next sowing (Bradford, 1986).
However, the drying and storage consequences on maintenance of beneficial effects obtained through osmoconditioning are as yet unresolved (Bray, 1995).

Seed moisture content and storage temperature are considered the main factors in maintaining viability. Seed moisture content during storage or before water uptake influences subsequent germination, since seeds with low moisture are particularly susceptible to stresses during water uptake (Ward \& Powell, 1983).

The vigour of stored seeds can be increased with priming, with a decrease in costs and reduction in number of collections. The seeds can then be used for a longer period of time a stock of viable seeds maintained to for reforestation programs in degraded areas or for the recovery of native forests.

The objectives of the present work were to determine the influence of different osmotic potentials on the imbibition curve time of $C$. excelsa seeds, as well as to verify the effect of osmoconditioning in different potentials, followed by drying and storage, on germination.

\section{MATERIAL AND METHODS}

This work was carried out at the Laboratory of Ecophysiology of Seed Germination, Botany Department of the Federal University of São Carlos, in São Carlos, São Paulo State, Brazil. $C$. excelsa seeds used in this study were collected on the campus of the Universidade Estadual Paulista (UNESP) in Jaboticabal, São Paulo, in July 1997, and maintained in glass packing, under conditions of low temperature $\left(5^{\circ} \mathrm{C}\right)$ and moisture content $11 \%$ U.R. until 1999.

The seeds were originally selected for color, size, and state of preservation. C. excelsa seeds present a hard and impermeable integument, one of the characteristics of the Fabaceae family. To overcome mechanical dormancy and accelerate the germination process besides making it uniform, a pre-germination treatment using concentrated sulphuric acid for 25 minutes was applied (Jeller \& Perez, 1999).

\section{Determination of imbibition curve}

One thousand (1000) seeds were selected, submitted to chemical scarification with $\mathrm{H}_{2} \mathrm{SO}_{4}$ conc., and placed in Petri dishes $(9 \times 9 \mathrm{~cm})$ with 
two sheets of filter paper, where $40 \mathrm{ml}$ of polietilenoglicol solution (PEG 6000) were added in the following potentials: $-0.2,-0.4,-0.6 \mathrm{MPa}$, or in distilled water. The osmotic potential of each solution, according to PEG concentration and temperature, was calculated according to Villela et al. (1991). The Petri dishes were then closed, covered with PVC film, and stored at $20^{\circ} \mathrm{C}$.

One sub-sample (20 units) was evaluated at 6-hour intervals for 240 hours as to the emergence of the radicle; afterwards the seeds were rinsed with distilled water, dried superficially with absorbent paper, weighed with an analytic balance, stored at $80^{\circ} \mathrm{C}$ for 48 hours, and transferred to a desiccator with silica gel, where they remained until reaching ambient temperature, when they were weighed again.

With the obtained values, it was possible to calculate the difference between the initial and fresh weight and between fresh and dry weight of each sample, and to determine the median values of these differences.

Evaluation of the seed osmoconditioning, followed by drying and storage

In this stage, four sub-samples of 400 seeds were selected, and after chemical scarification, each batch was immersed in $30 \mathrm{ml}$ of PEG solutions $(-0.2,-0.4$, and $-0.6 \mathrm{MPa})+0.2 \%$ of Captan fungicide and distilled water in Petri dishes and stored at $20^{\circ} \mathrm{C}$. A 100 seed sub-sample (control) was placed in Petri dishes (4 replicates of 25 units per dish) over two sheets of filter paper containing $6 \mathrm{ml}$ of distilled water and put to germinate at $27^{\circ} \mathrm{C}$ (Jeller \& Perez, 1999).

The osmotic potentials used were obtained based on the results of the germination tests of $C$. excelsa seeds under water stress (Jeller \& Perez, 2001); only osmotic potentials presenting at least $50 \%$ germination were used.

Seed imbibition time under each osmotic condition was determined based on the results of the imbibition test in seeds under water stress prior to radicle emergence. After the respective period of osmotic conditioning, each batch was removed from the germination chamber and the seeds were washed rapidly (5 seconds) in running water, in order to remove adsorbed PEG solution, they were then divided into two batches of 200 units that were submitted to the following drying treatments: a) superficial drying with paper towels, during 5 minutes;

b) superficial drying with paper towels and, storage at $25^{\circ} \mathrm{C}$ and $20 \%$ U.R., until reaching weight prior to osmotic conditioning and drying (approximately 48 hours).

After drying, each batch of 100 seeds was divided into two batches, and one of them was stored during 15 days at $5^{\circ} \mathrm{C}$; the other was sent to germinate at $27^{\circ} \mathrm{C}$. The treatments were as follows:

- control: seeds without osmotic conditioning

- T1: conditioned only

- T2: conditioning followed by drying

- T3: conditioning followed by storage

- T4: conditioning followed by drying and storage.

After the respective treatments, the seeds $(4 \times 25)$ were placed in Petri dishes over 2 sheets of filter paper with $6 \mathrm{ml}$ of distilled water and left to germinate at $27^{\circ} \mathrm{C}$ (Jeller \& Perez, 1999). The experimental design was complete randomized, in a $(4 \times 2 \times 2)+1$ factorial arrangement, corresponding to the osmotic potentials of the water and PEG solutions $(-0.2,-0.4$, and $-0.6 \mathrm{MPa})$, drying, storage, and control, respectively. The parameters analized were the germination percentage and mean germination time. Statistical analysis was performed through an ANOVA and mean comparisons made were through Tukey test at $\mathrm{p}<0.05$.

\section{RESULTS AND DISCUSSION}

\section{Imbibition}

Curves of imbibition of C. excelsa seeds in PEG solutions with different osmotic potentials at $20^{\circ} \mathrm{C}$ appear in Fig. 1. The trends of the imbibition curves, independently of the osmotic potential, show that the water uptake in $C$. excelsa seeds follows the triphasic pattern proposed by Bradford (1995).

Water uptake with different potentials was very similar during the first 12 hours, corresponding to the first phase (phase I), according to the triphasic pattern of seed imbibition. This first phase is characterized by fast water uptake in a short period of time, mainly due to the matric potential of seed tissues. In this phase, both dead and live seeds show similar behavior. 


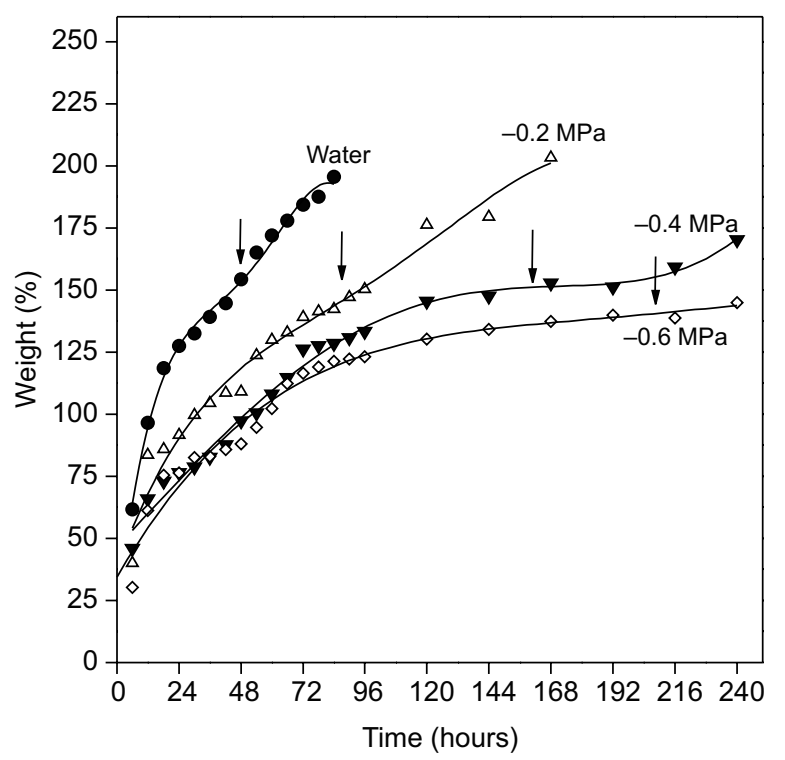

Fig. 1 - Curves of imbibition Cassia excelsa seeds in PEG solutions with different osmotic potentials at $20^{\circ} \mathrm{C}$. The arrows indicate beginning radicle emergence.

In phase II, absorption is slower and less intense than in the previous one: the absorbed water percentage was highest in distilled water and decreased with the reduction of osmotic potential. This phase includes preparatory metabolic events preceding the emission of the primary root, which marks the establishment of the phase III, characterized by a renewal of absorption, the growth of the embryonic axis, and radicle emergence. Reduction of the osmotic potentials accompanies reduction of the quantity of imbibided water, as happens with two other forest species, Dalbergia nigra (Borges et al., 1991) and Esenbeckia leiocarpa (Córdoba et al., 1995).

As the osmotic potential decreases, phase II of the water uptake process is extended, implying a delay in radicle emergence, as shown also in results of Bujaslki et al. (1991) and Tarquis \& Bradford (1992), who used PEG 6000 in seed imbibition and observed a reduction in the velocity of tissue hydration, a lengthening of phase II, and consequently more time for cell membranes reorganization and metabolic processes development.

For osmoconditioning, the seeds of C. excelsa were taken from the medium in this phase preceding radicle emergence, and terminated germination in different mediums from those in which the first phases occurred. The times required for conditioning in distilled water or PEG $(-0.2$, -0.4 , and $-0.6 \mathrm{MPa}$ ) were $48,72,96$, and $168 \mathrm{~h}$, respectively. The lower the osmotic potential, the greater the time to complete phase II imbibition.

Mean emergence time is greater when water availability is smaller, preventing in this way the occorrence of membrane damage during the imbibition phase (Fugikura \& Karssen, 1992).

Imbibition velocity depends not only on the osmotic potential of the solution but also on its properties, e. g., viscosity. Water uptake the seeds is a process highly conditioned by the physicochemical properties, controlled in turn by the properties of water (Eira, 1988). Imbibition is thus related to colloidal properties, under the influence of environmental conditions and the composition of the solvent, all of which affects the process velocity.

\section{Osmoconditioning}

There were significant differences in germination percentages in C. excelsa seeds osmotically conditioned in PEG solutions, as seen in Fig. 2. The osmoconditioning was effective in maintaining seed germination of $C$. excelsa when compared with the control (92\%). 


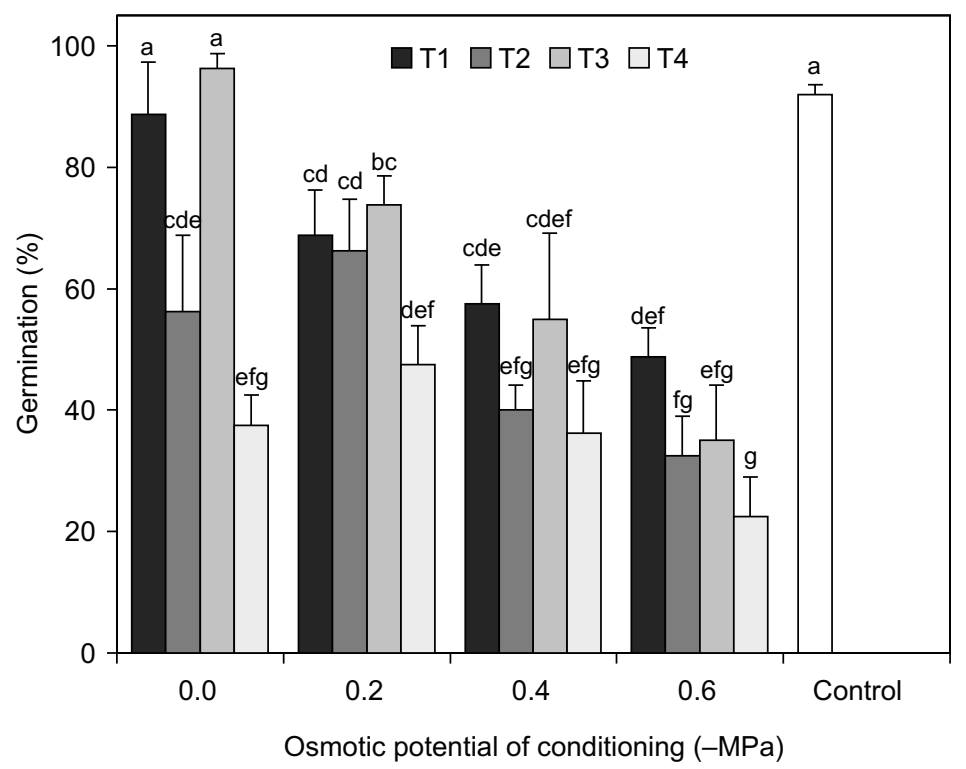

Fig. 2 - Germination percentage of Cassia excelsa seeds after drying and storage in different osmotic conditionings. T1: only conditioned; T2: conditioning followed by drying; T3: conditioning followed by storage; T4: conditioning followed by drying and storage.

With the exception of the seeds conditioned only with distilled water $(\mathrm{T} 1,88.75 \%)$ or conditioned and then stored (T3, 96.25\%), no reduction in germination traceable to water potentials was observed.

For the seeds of treatment $\mathrm{T} 1$, the highest germination percentage occurred in water, while in PEG solutions the results were not significant. However, in seeds dried after conditioning, followed or not by a storage period (T2 and T4), at $-0.2 \mathrm{MPa}$ occurrences of slight percentage increases were observed.

Conditioning with distilled water (T1 and T3), was beneficial to seed germination, without the damaging effects of rapid imbibition, as observed by Giúdice et al. (1998) and Braccini et al. (1999) in soybean seeds. Such detrimental effects are attributable to anaerobic respiration processes resulting from factors like reduced integrity of cell membranes, increases in micro-organism activity, solute leakage, or even low availability of oxygen (Armstrong \& McDonald, 1992).

However, when the seeds were dried after conditioning, significant reductions of germination
(T2 and T4) were observed and seed drying as shown to revert the beneficial effects of the treatment in all osmotic potentials. These findings agreed with those of Carpi et al. (1996) and Motta \& Silva (1999), who observed lower germination percentages in pre-conditioned seeds submitted to drying, in relation to non-conditioned ones. However, Khan et al. (1983) showed that the beneficial effect of conditioning remained after seed drying.

According to Bodsworth \& Bewley (1981), the greater the increase in drying period, the potentially greater the intensity of reversion, thus agreeing with Heydecker \& Wainwright (1976), who reported that seeds must be used immediately after treatment in order to retain the maximum benefit. Brocklehurst et al. (1987) emphasize that care with drying conditions is actually the main factor in preserving the physiological advancage obtained by osmoconditioning.

In relation to the maintenance of the osmotic conditioning effect in $C$. excelsa seeds during 15day storage at $5^{\circ} \mathrm{C}(\mathrm{T} 3)$, there was no loss of the beneficial effect of treatment in distilled water, but in PEG solutions the losses became significant. 
However, in seeds dried before storage (T4) there was a significant loss of germination percentage obtained by osmotic conditioning in water and -0.2 and $-0.4 \mathrm{MPa}$, and no differences with the reduction of these potentials, with the exception of the smallest osmotic potential tested (-0.6 MPa), for which the loss was significant.

Mean germination times of $C$. excelsa seeds were not reduced by osmoconditioning, when compared to control (3.13 days), as shown in Fig. 3 . When the seeds were only conditioned (T1), a statistical difference was observed between 0.0 and 0.6 MPa potentials. However, in treatments where the seeds were dried and stored (T3) after osmoconditioning, there were significant increases in mean germination times when compared to the seeds which were only conditioned (T1).

It has been suggested that the positive effects of osmoconditioning followed by dehydration are more evident in seeds with high deterioration levels or low vigour (Carvalho et al., 2000), however, C. excelsa seeds presented high germination percentages for the control $(92 \%)$ or when treated seeds were submitted to adverse conditions (Bradford, 1986). The dehydration of seeds involves changes in cell membranes that can predispose embryonic tissues to damage during imbibition (Woodstock \& Tao, 1981), thus the control of seed dehydration can afford a reversion in physiological quality either through the repair process of membranes (Pandey, 1988; Armstrong \& McDonald, 1992) or, possibly, by a metabolic reorganization at the cellular level (Pandey, 1988).

According to Senaratna et al. (1985), seeds are generally tolerant to dehydration in maturity and during the first stages of germination, but when they reach their critical stage they become susceptible to injury by dehydration. This fact does not justify reducing of the germination potential of $C$. excelsa seeds, since they were maintained under imbibition followed by dehydration before reaching the third phase (phase III) of the germination process in which occurs radicle emergence.

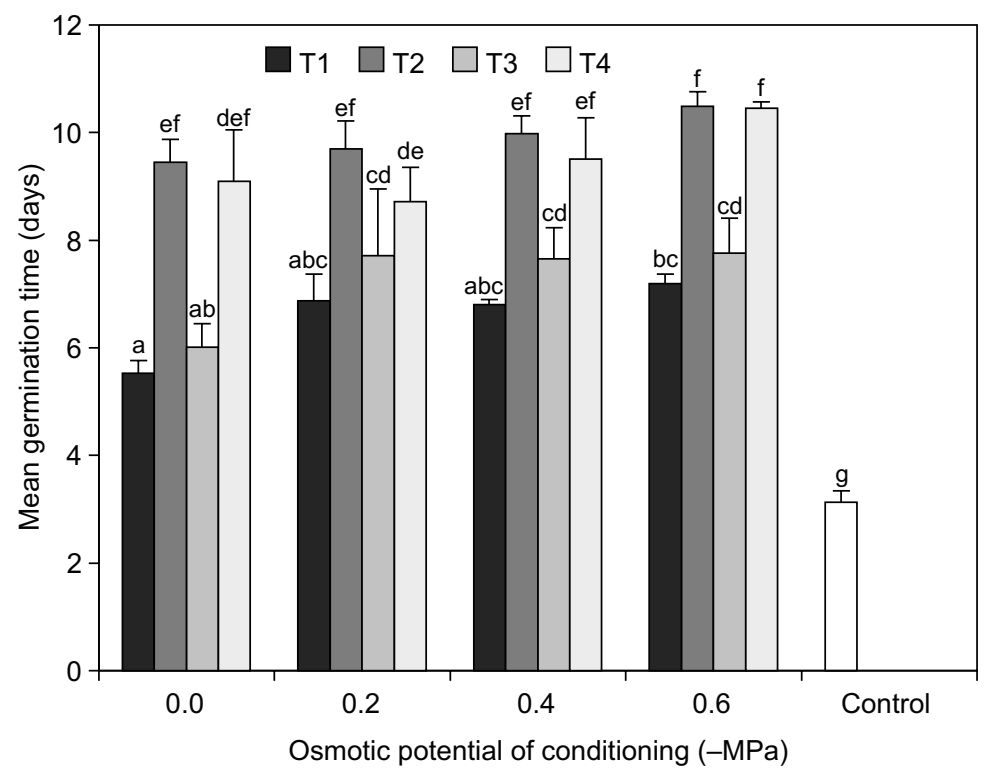

Fig. 3 - Time of germination of Cassia excelsa seeds after drying and storage in different osmotic conditions. T1: only conditioned; T2: conditioning followed by drying; T3: conditioning followed by storage; T4: conditioning followed by drying and storage. Control: nonconditioned seeds. Columns with the same letter do not differ significantly (Tukey, $\mathrm{p}<0.05$ ). 


\section{CONCLUSIONS}

- The lower the osmotic potential, the higher the time required for osmoconditioning.

- The highest germination percentages were achieved after conditioning with distilled water.

- Seed drying after osmoconditioning reverts the positive effects obtained in all osmotic potentials.

- Seed storage at $5^{\circ} \mathrm{C}$ during 15 days preserves the responses obtained by the osmoconditioning in distilled water.

\section{REFERENCES}

ARMSTRONG, H. \& McDONALD, M. B., 1992, Effects of osmoconditioning on water uptake and electrical condutivity in soybeans seeds. Seed Sci. Technol., 20: 391-400.

BODSWORTH, S. \& BEWLEY, J. D., 1981, Osmotic priming of seeds of crop species with polyethylene glicol as a means of enhancing early and synchronous germination at cool temperatures. Can. J. Bot., 59: 672-676.

BORGES, E. E. L., VASCONCELOS, P. C. S., CARVALHO, D. V. \& BORGES, R. C. S., 1991, Estudos preliminares sobre o efeito do estresse hídrico na germinação de sementes de Jacarandá-da-Bahia (Dalbergia nigra) e Cedro-rosa (Cedrela fissilis). Rev. Bras. Sem., 13: 115-118.

BRACCINI, A. L., REIS, M. S., MOREIRA, M. A. \& SCAPIM, C. A., 1997, Avaliação das alterações bioquímicas em sementes de soja durante o condicionamento osmótico. Rev. Bras. Sem., 19: 116-125.

BRACCINI, A. L., REIS, M. S., SEDIYAMA, C. S., SCAPIM, C. A. \& BRACCINI, M. C. L., 1999, Avaliação da qualidade fisiológica de sementes de soja, após o processo de hidratação-desidratação e envelhecimento acelerado. Pesq. Agrop. Bras., 34: 1053-1066.

BRADFORD, K. J., 1986, Manipulation of seeds water relations via osmotic priming to improve germination under stress conditions. Hortsci., 59(2): 672-676.

BRADFORD, K. J., 1995, Water relations in seed germination. In: Y. Kigel \& G. Galili (ed.), Seed development and germination. Marcel Dekker, New York, $13^{\circ}$ vol., pp. 351-356.

BRAY, C. M., 1995, Biochemical processes during the osmopriming of seeds. In: Y. Kigel \& G. Galili (ed.), Seed development and germination. Marcel Dekker, New York, $28^{\circ}$ vol., pp. 767-789.

BROCKLEHURST, P. A., DEARMAN, J. \& J. DREW, R. L. K., 1987, Recent developments in osmotic treatment of vegetable seeds. Acta Hort., 215: 193-201.

BUJALSKI, W., NIENOW, A. W. \& PETCH, G. M., 1991, The bulk priming of leek seeds. The influence of oxigenenriched air. Proc. Biochem., 26: 281-286.
CARPI. S. M. F., BARBEDO, C. J. \& MARCOS-FILHO, J., 1996, Condicionamento osmótico de sementes de Cedrela fissilis Vell. Rev. Bras. Sem., 18: 271-275.

CARVALHO, L. F., MEDEIROS-FILHO, S., ROSSETTI, G. \& TEÓFILO, E. M., 2000, Condicionamento osmótico em sementes de sorgo. Rev. Bras. Sem., 22: 185-192.

CÓRDOBA, G. A. T., BORGES, E. E. L., BORGES, R. C. G. \& NEVES, J. C. L., 1995, Osmocondicionamento em sementes de Esenbeckia leiocarpa Engl. (guarantã). Rev. Bras. Sem., 17: 217-226.

EIRA, M. T. S., 1988, Condicionamento osmótico de sementes de alface (Lactuca sativa $L$.): efeitos sobre a germinação e desempenho sob estresse hídrico, salino e térmico. Dissertação de Mestrado, Escola Superior de Agricultura Luíz de Queiroz, Universidade de São Paulo.

FU, J. R., LU, X. H., CHEN, R. Z., ZHANG, B. Z., LIU, Z. S. \& CAI, D. Y., 1988, Osmoconditioning of peanut (Arachis hypogaea L.) seeds with PEG to improve vigour and some biochemical activities. Seed Sci. Technol., 16: 197-212.

FUGIKURA, Y. \& KARSSEN, C. M., 1992, Effects of controlled deterioration and osmopriming on protein synthesis of cauliflower seeds during early germination. Seed Sci. Res., 2: 23-31.

GIÚDICE, M. P. D., REIS, M. S., SEDIYAMA, C. S., SEDIYAMA, T. \& MOSQUIM, P. R., 1998, Avaliação da qualidade fisiológica de sementes de soja submetidas ao condicionamento osmótico em diferentes temperaturas. Rev. Bras. Sem., 20(2): 254-262.

HEYDECKER, W. \& WAINWRIGHT, H., 1976, More rapid and uniform germination of Cyclamen persicum L. Sci. Hort., 5: 183-189.

JELLER, H. \& PEREZ, S. C. J. G. A., 1999, Estudo da superação da dormência e da temperatura em sementes de Cassia excelsa Schrad. Rev. Bras. Sem., 21: 32-40.

JELLER, H. \& PEREZ, S. C. J. G. A., 2001, Efeitos dos estresses hídrico e salino e da ação de giberelina em sementes de Senna spectabilis. Rev. Cien. Flor, 11: 93-104.

KHAN, A. A., PECK, N. H., TAYLOR, A. G. \& SAMIMY, C., 1983, Osmoconditioning of beet seeds to improve emergence and yield in cold soil. Agron. J., 75: 788-794.

KHAN, A. A., 1992, Preplant physiological seed conditioning. Hort. Rev., 13: 131-181.

LOPES, H. M., ROSSETTO, C. A. V. \& CARNEIRO, V., 2000, Embebição de sementes de cenoura (Daucus corota L.) em diferentes potenciais osmóticos por dois métodos. Rev. Bras. Sem., 22: 81-87.

McDONALD, M. B., 1998, Seed quality assessment. Seed Sci. Res., 8: 265-275.

MOTTA, C. A. P. \& SILVA, W. R., 1999, Desempenho fisiológico e sanidade de sementes de trigo submetidas a tratamentos de hidratação/desidratação. Sci. Agric., 56: 571-580.

NATH, S., COOLBEAR, P. \& HAMPTON, J. G., 1991, Hydration-dehydration treatments to protect or repair stored Karamu wheat seeds. Crop Sci., 31: 822-826. 
PANDEY, D. K., 1988, Priming induced repair en french bean seeds. Seed Sci. Technol., 16: 527-532.

SENARATNA, T., McKERSIE, B. D. \& STINSON, R. H., 1985, Antioxidant levels in germinating soybean seed axes in relation to free radical and dehydration tolerance. Plant Physiol., 78: 168-171.

SMITH, P. T. \& COOB, B. G., 1992, Physiological and enzymatic characteristics of primed, re-dried, and germinated pepper seeds (Capsicum annuиm L.). Seed Sci. Technol., 20: 503-513.

SUNG, F. J. M. \& CHANG, Y. H., 1993, Biochemical activies associated with priming of sweetcorn seeds to improve vigor. Seed Sci. and Technol., 21: 97-105.

TARQUIS, A. M. \& BRADFORD, K. J., 1992, Prehydration and priming treatments that advance germination also increase the rate of deterioration of lettuce seeds. J. Expt. Bot., 43: 307-317.
VERTUCCI, C. W., 1989, The kinetics of seed imbibition. Crop Science Society of America (Seed moisture), 14: 93115.

VILLELA, F. A., FILHO, L. D. \& SEQUEIRA, E. L., 1991, Tabela de potencial osmótico em função da concentração de polietileno glicol 6000 e da temperatura. Pesq. Agrop. Bras., 26: 1957-1968.

WARD, F. H. \& POWELL, A. A., 1983, Evidence for repair processes in onion seeds during storage at high seed moisture contents. J. Expert. Bot., 34: 277-282.

WOODSTOCK, L. W. \& TAO, K. L. J., 1981, Prevention of imbibitional injury in low vigor soybean embryonic axes by osmotic control of water uptake. Physiol. Plantar, 51: 133-139. 